\title{
Dyscbiridium belovi sp.n., the first peleciine from Indochina (Coleoptera: Carabidae)
}

\section{Dyschiridium belovi sp.n. - первый представитель трибы Peleciini из Индокитая (Coleoptera: Carabidae)}

\author{
D.N. Fedorenko \\ A.H. Федоренко
}

\begin{abstract}
A.N. Severtsov Institute of ecology and evolution, Leninsky pr. 33, Moscow 119071 Russia.
Институт проблем экологии и эволюции им. А.Н. Северцова, Российская Академия Наук, Ленинский пр-т, Москва 119071 Россия, dmitri-fedorenko@yandex.ru
\end{abstract}

KEY WORDS: Coleoptera, Carabidae, Peleciini, Dyschiridium, new species, first record, Vietnam.

КЛЮЧЕВЫЕ СЛОВА: Coleoptera, Carabidae, Peleciini, Dyschiridium, новый вид, первая находка, Вьетнам.

ABSTRACT. A new species of ground beetles, Dyschiridium belovi sp.n., is described from the mountains of southern Vietnam. This is the first record of a member of the genus Dyschiridium Chaudoir, 1861 outside Africa, and the first record of a member of Peleciini in Asia outside the Indian subcontinent.

РЕЗЮМЕ. Новый вид жужелиц, Dyschiridium belovi sp.n., описан из гор юга Вьетнама. Это первая находка представителя рода Dyschiridium Chaudoir, 1861 за пределами Африки и первая находка пелециин в Азии восточнее Индостана.

\section{Introduction}

Members of the tribe Peleciini are small to large, rarely encountered apterous carabids. Both the adults and larvae are known to feed on leptodesmid myriapods [Salt, 1928; Erwin, 1979; Straneo \& Ball, 1989]. The tribe is fairly small yet widespread in the tropics in the Americas, Africa, and Indian subcontinent. Only two genera and four species occur outside the tropics; they are confined to Tasmania or southeastern Australia and are all members of the subtribe Agonicina. Out of the total of three Paleotropical genera, two (Disphaericus Waterhouse, 1842 and Dyschiridium Chaudoir, 1861, with 23 species combined) are Afrotropical in distribution; the third genus, Ardistomopsis Straneo et Ball, 1989, includes five species hitherto reported from South India or Sri Lanka only.

The Neotropical and Oriental species have been revised quite recently [Straneo \& Ball, 1989] based on a comparative analysis of many characters, including mouthparts. The African species have not been covered by the revision, and their relationships, including to the Oriental elements, need further clarification.

During several expeditions sponsored by the RussoVietnamese Tropical Center, a new peleciine species has been collected in mountain forests of southern Vietnam. It is described below as a member of the genus Dyschiridium. This means a great eastward extension of the known range of the genus, previously known from Africa only.

Holotype and paratypes are deposited in the Zoological Museum of the Moscow State University and in the author's synoptic collection at A.N. Severtsov Institute of Ecology \& Evolution, Russian Academy of Sciences, Moscow.

\section{Dyschiridium belovi Fedorenko, sp.n.} Figs 1-10.

MATERIAL. Holotype $\bigcirc$ labelled: "S Vietnam, Dak Lak Prov[ince]. / Chu Yang Sin Nat[io]n[al]. Park, $12^{\circ} 222$ 403N $108^{\circ} 212113 \mathrm{E} / 1.5 \mathrm{~km}$ W of Chu Pan Phan Mt / h=1650 m [asl], 30.III-11.IV.2012 / leg. D. Fedorenko". Paratypes: $0^{7}$, same data; + , same data, but taken 19.III-2.IV.2013; 2 9 , Lam Dong Prov[ince]. / Bi Doup - Nui Ba Nat[ure]. Res[erve] / env. Long Lanh / $12^{\circ} 102443 \mathrm{~N}, 108^{\circ} 402443 \mathrm{E} / \mathrm{h}=1400-1600 \mathrm{~m}$ [asl], 10.V.2009/ leg. D. Fedorenko.

DESCRIPTION. Body (Fig. 1) $9.5-10.9 \mathrm{~mm}$ in length (apparent body length, ABL, measured from apices of mandibles and apices of elytra), black, shiny, femora pitch-brown, slightly reddish, antennae and tarsi dark red to brownish red, palpi reddish, mandibles, except for their apices, and sometimes labrum very slightly reddish. Microsculpture very fine, isodiametric on head, well-visible at sides of frons, less so along middle, obliterated or very faint on neck, sometimes slightly transverse at middle of frons just behind clypeus; pronotum and elytra with fine, strongly transverse microreticulation. Dorsum sparsely but regularly micropunctate throughout, underside smooth and impunctate.

Head typical to the genus, with sides diverging apicad before eyes; eyes prominent, convex, encircled by very narrow and short genae in posterior half; angle between gena (temple) and neck acute; neck constriction deep and straight; frontoclypeal suture short, transverse, ill-defined; frontal sulci divergent, fine just behind clypeus, thence running as very deep oblong foveae, each with a rather deep pit at both ends, and abruptly terminating at the level of anterior supraocular seta; a small but very deep pit present between 


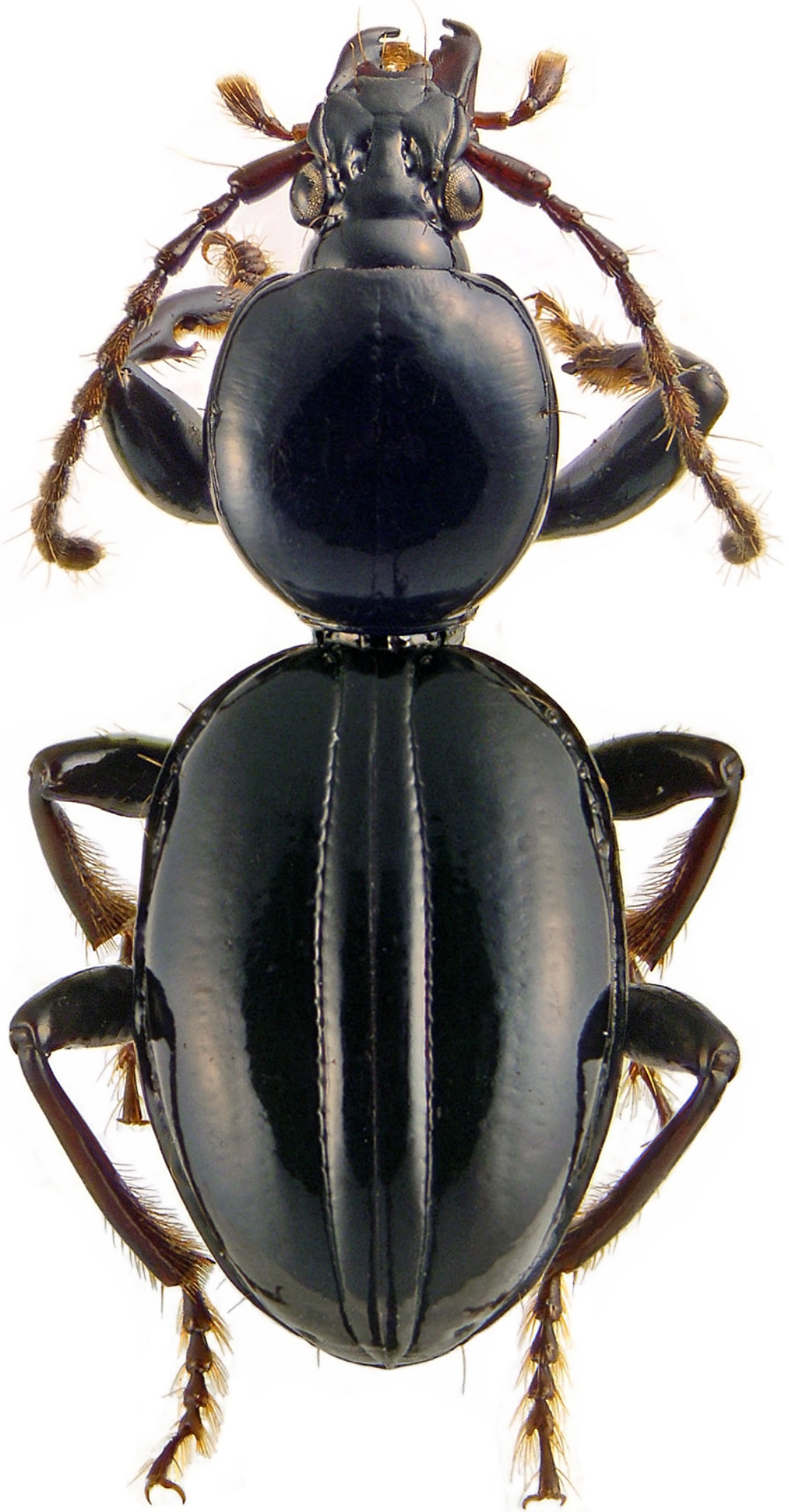

Fig. 1. Dyschiridium belovi sp.n., dorsal habitus.

Pис. 1. Dyschiridium belovi sp.n., общий вид. 
anterior and posterior supraocular setae. Clypeus bisetose, barely concave to nearly truncate at front margin. Labrum bilobed, sexsetose, medial emargination very deep, U-shaped, inner four setae located in a deep submarginal groove, medial pair on a small tubercle in the emargination. Right mandible with anterior (distal) and posterior (proximal) retinacular teeth barely separated; basal occlusal margin with numerous basal notches, but without basal setae dorsally. Antennae slightly surpassing base of elytra, pubescent from antennomere 4 onwards; scape with a long seta; pedicel with no to very few short setae in addition to verticillate setae; antennomere 3 with a few to several short setae between verticillate ones; scape slightly shorter than antennomeres 2 and 3 combined, $3^{\text {rd }}$ antennomere $1.35-1.50$ times as long as $2^{\text {nd }}$ and hardly (1.06-1.10 times) longer than $4^{\text {th }}$.

Mentum asetose, with a very wide apical bead (homologous to apical bead and epilobes combined in other carabids) limited behind by a deep transverse groove; submentum bisetose. Maxillary stipes with a basal seta. Last two maxillary palpomeres and apical labial palpomere densely pubescent; apical maxillary palpomere about three times as long as preapical one, oblong-oval, subparallel-sided, slightly narrower apicad, with apex truncate but slightly convex; apical labial palpomere subtriangular, 2.5 and 2.1 times as long as wide at apex in male and female, respectively.

Prothorax globose, as wide as long, width/length ratio 0.98-1.03 (mean 1.0), almost twice (1.85-1.97 times, mean 1.88 ) as wide as head; apex straight, front angles rounded, adjacent to neck; sides almost evenly rounded, finely beaded throughout except just before peduncle, with a single lateral seta at mid-length just inside the bead; hints of front transverse impression discernable at sides only; mid-line fine yet well-defined, deeper in basal fifth, not quite reaching base and apex. Propleura tumid, well-visible from above, notopleura narrow, notopleural suture traceable. Prosternum narrowly beaded along front margin, rather deeply longitudinally sulcate in basal three fifths, prosternal process unbordered.

Apterous. Elytra strongly convex, elliptic, without shoulders, 1.36-1.41 (1.40) times as wide as pronotum, 1.39-1.49 (1.44) times as wide as long; striae obliterate, except for striae 1 and 8 which are entire and sulcate, former finely but distinctly crenulate in basal three fourths, latter minutely crenulate at least medially. Both lateral border and stria 1 reach a short but distinct basal border; an isolated setigerous pore just outside base of stria 1 and another one closer to stria 8 before apex. Umbilical setigerous pore series widely interrupted medially, divided into posthumeral group of 5-6 pores and preapical group of 6-7 pores.

Metaventrite beaded along basal margin. Abdomen conspicuously beaded along front margin as well as along lateral margins; sterna V to VII beaded basolaterally, along small triangular lobes of preceding sterna (IV to VI). Abdominal sterna each with a medial pair of setae, last sternite (VII) with a postmedian transverse row of large setigerous pores, 2-3 on each side in male, 3-4 in female, outer pore inserted close to apical margin.

Trochanters with a seta; pro-, meso- and metacoxa uni-, bi- and trisetose, respectively; profemur with a medial seta ventrally and another one at base of posterior surface; mesofemur at anteroventral edge with a submedial seta hardly

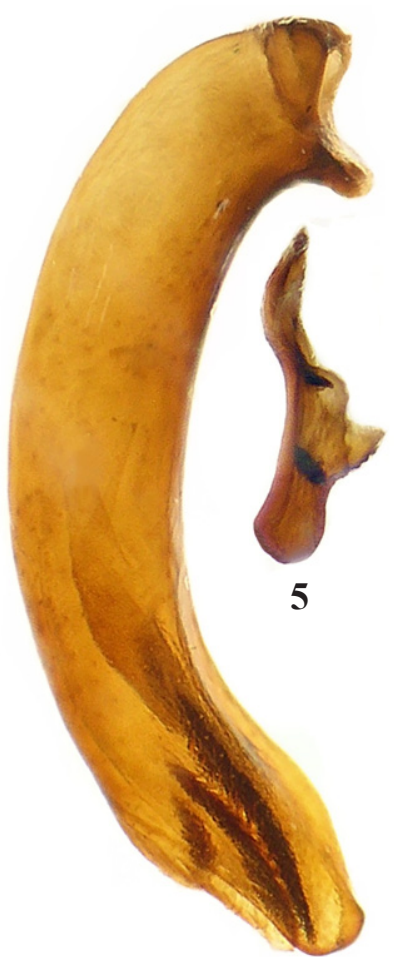

2

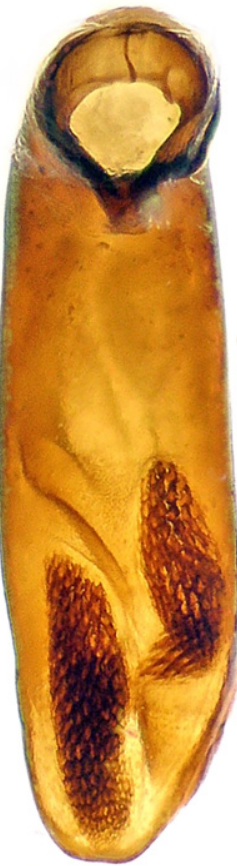

3

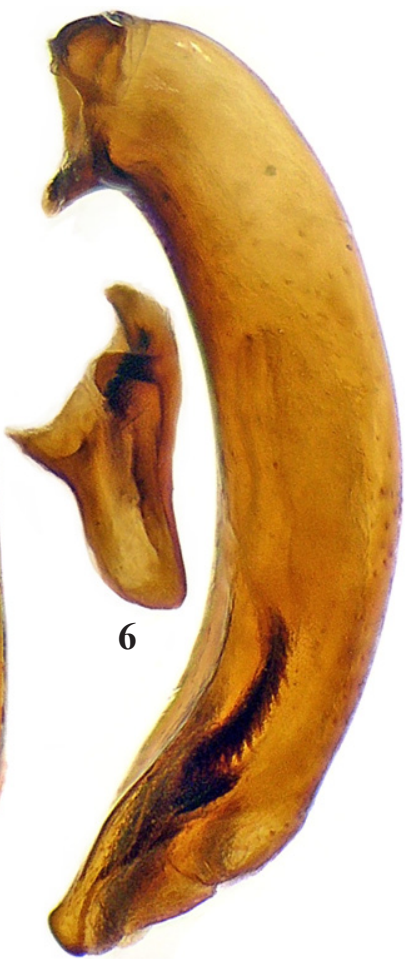

4

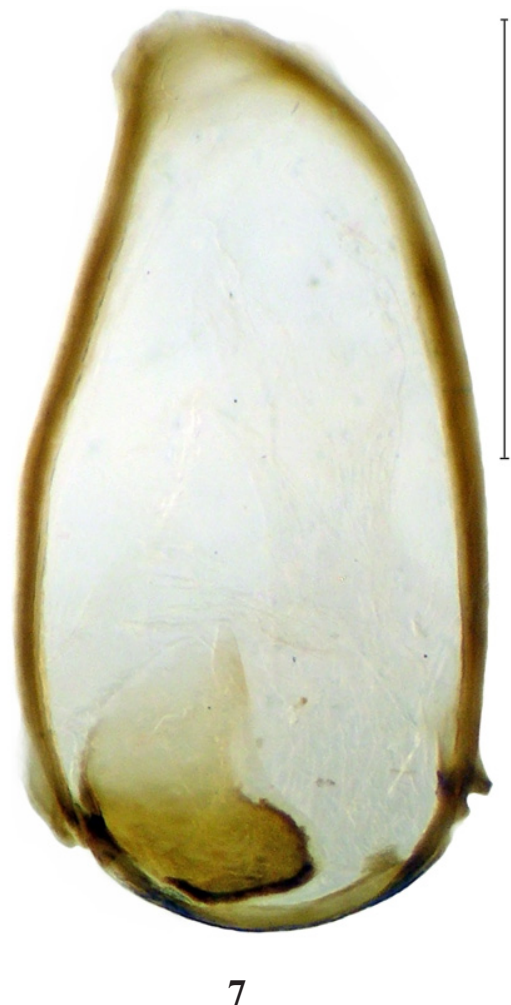

7

Figs 2-7. Dyschiridium belovi sp.n., male: $2-4$ - penis; 5 — right paramere; 6 - left paramere; 7 - tergite IX; 2 - right lateral view; 3 - ventral view; 4 -left lateral view; 7 - dorsal view. Scale bar $1 \mathrm{~mm}$.

Рис. 2-7. Dyschiridium belovi sp.n., самец: 2-4 - пенис; 5 - правая парамера; 6 - левая парамера; 7 - тергит IX; 2 - справа, 3 - снизу; 4 - слева; 7 - сверху. Масштаб 1 мм. 
larger than numerous slightly shorter ones over the anatomically anterior side; metafemur bisetose, i.e., with basal and medial setae, at anterodorsal edge. Tibiae slightly arcuate, slightly broadened apicad, densely pubescent, except for at bases and along outer edges; pro- and mesotibia sharply toothed at apex of posterior or outer margin, respectively. Tarsi beneath with dense pubescence mixed with adhesive vestiture on basal four pro- and mesotarsomeres. Tarsomeres 1-4 each with a postmedian row of fairly long setae. Last tarsomere usually with two (basal and preapical) pairs of very long setae dorsally, a postmedian pair of longer setae laterally and two or three pairs of shorter preapical setae ventrally. Tarsomere 4 small, distinctly bilobed. Protarsomeres slightly transverse, only a little wider than mesotarsomeres.

Penis (Figs 2-7) cylindrical, slightly broadening apicad, with a small rounded apical orifice; apical lamella small, transversely truncate in ventral view, with a tiny blunt tooth at tip in lateral view; internal sac apically with five sclerotized patches of microspicules arranged into three groups as follows: (1) right-side group composed of two subequal oblong patches, one above the other, (2) left-side group consisting of a smaller dorsal patch perpendicular to an oblong ventral one, and (3) a small dorsalmost patch in submedian position.

Female genitalia (Figs 8-10): gonocoxite IX as described for Peleciina [Straneo \& Ball, 1989], gonosubcoxite
IX with a long anterior process densely covered with short spiniform setae. Bursa copulatrix large, sclerotized, with distinct isodiametric microsculpture, membranous in anterior third.

VARIABILITY. Two females from the Bi Doup - Nui Ba Nature Reserve are 10.6-10.9 $\mathrm{mm}$ in length, with $5+6$ umbilical setae on the elytra, whereas three specimens from the Chu Yang Sin National Park are 9.5-10.3 $\mathrm{mm}$ in length, with 5-6+7 setae.

DIAGNOSIS. Besides geographical distribution, the following combination of characters easily separates the new species from its African congeners: body stout, large, convex; pronotum globose; elytral striae 1 and 8 entire and very deep; the basal elytral bead short, reaching both lateral bead and stria 1; neck constriction deep; protarsomeres slightly rather than strongly transverse.

DISTRIBUTION. The Dalat plateau, southern Vietnam.

NAME. Is given after my good friend Vassily V. Belov (Maplewood, USA).

COMMENTS. We place the new species in Dyschiridium because it fits the character combination diagnostic of this genus, namely, the mandibles typical to Disphaericus and Dyschiridium; the elytral striae other than 1 and 8 totally obliterate; and the umbilical setigerous pores reduced in number and arranged into two separate groups.
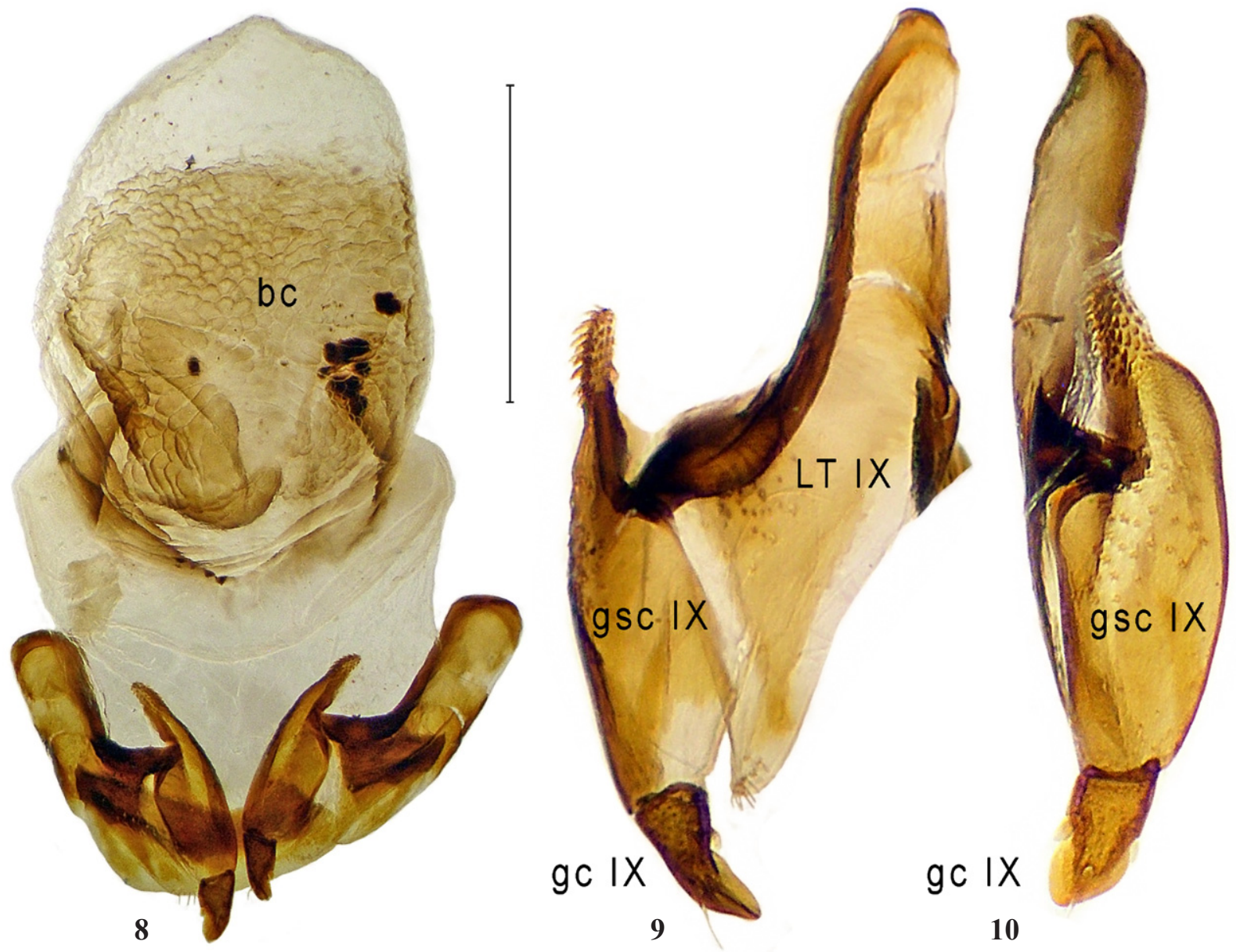

10

Figs 8-10. Dyschiridium belovi sp.n., female genitalia and reproductive tract: 8-9 - ventral view; 10 - left lateral view; bc - bursa copulatrix; gc IX — left gonocoxite IX; gsc IX — left gonosubcoxite IX; LT IX — laterotergite IX. Scale bar $1 \mathrm{~mm}$.

Рис. 8-10. Dyschiridium belovi sp.n., гениталии и половые пути самки: 8-9- снизу; $10-$ слева; bc - копулятивная сумка; gc IX - левый гонококсит IX; gsc IX - левый гоносубкоксит IX; LT IX - латеротергит IX. Масштаб 1 мм. 
This character combination is also consistent with in the African members of Dyschiridium, including two undescribed species before me. Otherwise, the African congeners tend to be quite different: most, or at least some, have a flattened body; elytra with stria 1 obliterated at least basally, and the basal border reduced; pronotum with the lateral bead conspicuously shortened basally and two lateral setae on each side; the protarsomeres strongly transverse, etc. To find out whether all of the species currently assigned to Dyschiridium do belong there, a complete revision is required, but that task is beyond the scope of this paper.

A number of minor inconsistencies in the revision by Straneo \& Ball [1989] should be pointed out. First, the authors mention two pairs of pronotal setae in Dyschiridium, even though $D$. lastii (Bates, 1886) and D. subdepressum (Kolbe, 1895), according to the descriptions, only have one. Second, the description of Ardistomopsis suggests that neither the transverse postocular groove nor the prominent basal ridge are characteristic to its member species. However, according to Schaum [1864] and Andrewes [1923], the postocular transverse groove (neck constriction) is deep in A. marginicollis (Schaum, 1864) and A. myrmex (Andrewes, 1923), and also the elytral stria 1 joins the marginal groove in the latter species. Another discrepancy is between the description of Ardistomopsis, that says the basal seta is missing on the maxillary stipes, and Table 2, where the seta is shown to be present in all the Paleotropical genera. Body length data should be slightly corrected for these genera as well. The standardized body length (SBL) used in the revision is actually $3.9-8.9 \mathrm{~mm}$ in Ardistomopsis, not $7-8.5 \mathrm{~mm}$ as indicated. Of course, SBL is not the same as ABL (apparent body length), but for Dyschiridium the indicated SBL of 3.0-9.0 $\mathrm{mm}$ is inconsistent with the actual ABL, which is $6-14 \mathrm{~mm}$. Similarly, Disphaericus clavicornis Kolbe, 1895 is $6.5 \mathrm{~mm}$ in apparent length, which is smaller than the SBL of $8.5-16 \mathrm{~mm}$ indicated in the revision for that genus.

Furthermore, recent placement of Dyschiridium natalicum (Westwood, 1864) into synonymy under D. lastii (Bates, 1886) by Häckel \& Farkač [2012] is unjustified because the former is half the size of the latter; otherwise, the name lastii Bates would have priority.
Finally, the discovery of a Dyschiridium in Indochina makes us revise the hypothesis on the origin of the Paleotropical peleciines. The widely disjunct distribution of Dyschiridium suggests a continuous range in the past, which means Dyschiridium and Ardistomopsis having been likely sympatric at least in India or in adjacent parts of Asia long after India separated from Gondwanaland. Because Indochina was never part of Gondwana, the Old World peleciines, Dyschiridium in particular, could have evolved in Africa, Asia, or India. Thus, the evolution of the Paleotropical Peleciini can not be explained at present with invoking the only continental drift, as suggested by Straneo \& Ball [1989].

\section{References}

Andrewes H.E. 1923. Descriptions of some new Carabidae from Ceylon // Spol. Zeyl. Vol.12. P.223-251.

Bates H.W. 1886. Tropical African Coleoptera, chiefly from the Zanzibar mainland // Ent. Month. Mag. Vol.22. P.188-197.

Chaudoir M. 1861. Beitrag zur Kenntniss einiger CarabicidenGattungen // Berlin. Entomol. Z. Bd.5. S.116-131.

Erwin T.L. 1979. A review of the natural history and evolution of ectoparasitoid relationships in carabid beetles // T.L. Erwin, D.R. Whitehead \& A.L. Halpern (eds.). Carabid beetles: their evolution, natural history and classification. Proceedings of the First International Symposium of Carabidology, Smithsonian Institution, Washington, D.C., August 21, 23, and 25, 1976. The Hague: W. Junk Pbls. P.355-367.

Häckel M., Farkač J. 2012. A check-list of the subfamily Panagaeinae Hope, 1838 of the world (Coleoptera: Carabidae) // Studies and Reports of Distr. Mus. Prague-East. Taxonom. ser. Vol.8. No.1-2. P.67-116.

Kolbe H.J. 1895. Coleopteren aus Afrika III // Entomol. Ztg., Stettin. Bd.66. S.345-366.

Salt G. 1928. Notes on the life history of Pelecium sulcatum Guerin // Psyche. Vol.35. P.131-134.

Schaum H. 1864. Beitrage zur Kenntnis der Carabicinen // Berl. Entomol. Z. Bd.8. S.114-126.

Straneo S.L., Ball G.E. 1989. Synopsis of the genera and subgenera of the tribe Peleciini, and revision of the Neotropical and Oriental species (Coleoptera: Carabidae) // Insecta Mundi. Vol.3. No.2. P.73-178. 